\title{
Motives and techniques of earnings management used in a global environment
}

\author{
Lenka Strakova, ${ }^{1, *}$ \\ ${ }^{1}$ University of Zilina, Faculty of Operation and Economics of Transport and Communications, \\ Department of Economics, Univerzitna 1, 01026 Zilina, Slovakia
}

\begin{abstract}
.
Research background: From a research perspective, it is very important to point out motives and used techniques of earnings management because it allows better identify the factors that drive the decision to practice earnings management. Motives of earnings management can be organized thematically into contractual obligations, asset pricing, or influencing external parties which are carried out through the use of various earnings management techniques.

Purpose of the article: The article aims to identify all possible motives leading to the practice of earnings management in companies in a global environment and to point out the individual techniques of earnings management, which are used to realize the individual motives.

Methods: The method of description and the method of classification of technical terms are used to specify in more detail the motives and techniques of earnings management used in the global environment.

Findings \& Value added: In a global environment exist strong motives for managers to practice earnings management. These motives include better pricing of securities, beating analysts' expectations, avoid negative earnings, show better performance than past, better compensation of managers, tax evasion, external finance attraction, concealment of poor performance, favorable contracts from suppliers, customers, lenders, and employees and avoiding technical default on debts covenants. Another dimension of earnings management is the stress level of managers builds up due to expectations of better performance by stakeholders. In a global environment, there are several techniques used to practice motives leading to earnings management. These techniques are described in more detail in the article.
\end{abstract}

Keywords: motives; techniques; earnings management; global environment

JEL Classification: $M 41 ; F 60$

${ }^{*}$ Corresponding author: lenka.strakova@fpedas.uniza.sk 


\section{Introduction}

Earnings management represents a complex [1] and compound phenomenon in the global environment. This phenomenon belongs to the integral and fundamental part of companies' business finance. [2] Earnings management occurs when managers use judgment in financial reporting and in structuring transactions to alter financial statements due to deceiving certain partners concerning the company's economic performance. It represents a selection of accounting policies made by the manager affecting revenues as well as the achievement of the positive performance of companies. [3] Earnings management occurs in a global environment in many companies that are motivated to manage their profits to create the impression of a prosperous company in the business world in the eyes of third parties. [4] Earnings management practices can exacerbate information asymmetry between stakeholders such as creditors, suppliers and investors, and the focal firm. [5] Misleading financial reporting harms all stakeholders since financial records are the primary source of information on financial stability, economic activity, and financial health of any company. [6] Different motives lead managers to use different techniques, which is a global business environment [7] that can be classified according to two types of earnings management. There is real earnings management which represents the activity where managers try to influence reported earnings through actions that substantially change the underlying cash flows thereby influencing reported earnings and accrual-based earnings management which operates within the accounting norms choices that try to obscure the true performance of companies.

\section{Methodology}

From a research perspective, it is very important to point out motives and used techniques of earnings management because it allows better identify the factors that drive the decision to practice earnings management. Motives of earnings management can be organized thematically into contractual obligations, asset pricing, or influencing external parties which are carried out through the use of various earnings management techniques. In the paper is used the method of description and the method of classification of technical terms are used to specify in more detail the motives and techniques of earnings management used in the global environment.

\section{Results and discussion}

\subsection{Earnings management motives}

The main aim of Earnings management is the achievement of certain purposes by the medium of manipulating relevant accounting practices, under generally accepted accounting principles, so that the earnings shown on financial reports achieve predetermined targets. Based on this definition, there are three major assumes:

1. Under generally accepted accounting principles, adjustments and changes are purposefully made to report earnings that meet the expected targets.

2. Accounting practices and the compilation of reports are manipulated purposefully to meet the expectations of management or certain individuals.

3. Creative adjustments or twisting of actual financial performances are made to meet operational targets. [8] 


\subsubsection{Compensation contract}

Managers of a company with earnings-based compensation contracts tend to adopt income increasing accounting for increased earnings. [9] Managers of the company may tend to choose income-reducing accounting methods if earnings fall below the lower limit or increase above the upper limit specified in the bonus plan. The theory of management compensation known as the bonus plan theory assumes that managers of the company are motivated to use earnings management to improve compensation because bonuses of management are often tied to company earnings. [10] Managers of the company are interested in maintaining earnings growth because of their effects on stock prices and because their compensations are often related to company earnings. Managers try to keep the profit between its minimum and maximum level [11] because then they can ensure the growth of their bonuses by overestimating the reported profit. If the reported profit acquires the maximum possible value of the bonus, the motivation of managers will consist of accumulating the reported profit for further use by taking certain steps leading to the reduction of the reported profit. [9]

\subsubsection{Debt covenant}

Debt covenant represents a relationship based on agreement among companies and their lenders in which financial ratios are set by creditors as a benchmark that companies cannot breach. A typical example of a debt covenant is the return on assets ratio, equity ratio, or interest coverage. Since those ratios are calculated from data in the financial statements of the company, managers can somehow manage the numbers and this is one of several motivators for earnings management. One of the authors on the motives that encourage the emergence of earnings management examined the approach of the company's managers to the debt contract, based on which he found that companies with the same level of business, whose business behavior leads to breach of debt contract, manage their revenues upwards. [12] Other authors point to the debt covenant as part of an accounting theory that significantly influences the choice of accounting methods within a given company. Other authors point to debt covenant as part of an accounting theory that significantly influences the choice of accounting methods within a given company, suggesting that the company's managers may shift profits from the following period to the current period. [13]

\subsubsection{Political costs}

Costs are an essential motive for the implementation of earnings management. [14] Political costs are associated with the assumption that ceteris paribus is applied when there is a situation where the greater the political costs that a firm will incur, the more likely it is that the manager will choose accounting methods that will shift reported revenue from the current period to the next.

\subsubsection{Providing information to investors}

Investors seek to obtain information that will be useful to them in predicting the future performance of the business. Earnings management is a tool for disclosing inside information to investors, which improves the information function of the company's financial statements. Various reasons motivate companies to apply to earnings management. Many of the authors dealing with this issue assume that stable earnings of the company are, in contrast to variable earnings, able to support a higher level of dividends. Earnings variability is therefore interpreted as a significant measure of a company's overall 
risk directly affecting the investor's capitalization rate, adversely affecting investors' subjective expectations of future earnings and dividends, as well as the value of the company's shares. If managers apply earnings management responsibly, external entities can conclude from the company's financial statements about the future profitable situation of the company.

\subsubsection{Manager reputation}

Reputation is related to result from the performance of managers, which reflects on the financial statements of the company. Hence, failing to meet the forecasted number is often pointed to managerial failure and the consequence of it can cost managers their jobs. That is why managers try to manipulate their earnings.

\subsection{Real earnings management techniques}

\subsubsection{Big Bet on the Future}

It is a technique in which one company acquires another company. This technique is like a bet for the future, one of the purposes of which is to increase the acquiree's reported income under the conditions of a properly planned acquisition recorded by one of the accounting methods, for example by purchase. The technique of Big Bet on the Future contains two sub techniques such as the depreciation of research and development costs incurred for the company and the process of integrating the earnings of the acquired company into consolidated earnings. The first sub technique represents writing off part of the purchase price compared to current income in the year of the acquisition, which results in the protection of future income from the fees, the value of which will increase compared to their original value. The second sub technique represents

\subsubsection{Flushing investing portfolio}

Companies in a global environment have the opportunity to buy shares from other companies to invest excess funds or to achieve a specific strategic alliance. [14] An enterprise can manage profits by investing in marketable and available-for-sale securities. Gains or losses arising from the sale of marketable securities or changes in their market value are recognized in operating income. In the event of a change in the market value of available-for-sale securities, the gain or loss is recognized in other comprehensive income. If a situation arises in which securities for sale are sold, the gain on the securities or loss is recorded in the company's operating income. If the actual sale of the securities does not take place, we speak of unrealized gains or losses, which are recorded in profit, but not in operating profit. [15]

\subsubsection{Throw out a problem child}

This is a technique of removing a branch that does not achieve a sufficient level of performance, which may limit the branch's profit growth in the following period. This removal can take place in three ways, namely by selling a branch, a special purpose entity, and establishing a spinning of the branch. In the case of a sale of a branch, the gain on the sale is recognized in the current accounting year in which the sale took place. They are subsidiaries owned by larger corporations to acquire and finance certain assets and to avoid risk relating to the parent company's banker. In a global environment, it represents the spin- 
off of a subsidiary from the parent company, resulting in a division of shares between the current shareholders who acquire the status of the owner of the spin-off company.

\subsubsection{Shrink the ship}

It is the purchase of own shares between the company and the owners of equity securities, while no profit is recognized in the financial statements. The primary goal is to increase earnings per share, which points to the company's profitability. [16]

\subsubsection{Other real earnings management techniques}

- delaying sales,

- accelerating R\&D or advertising expenditures,

- postponing R\&D or advertising expenditures,

- sale/leaseback and asset exchange technique.

\subsection{Accrual-based earnings management techniques}

\subsubsection{Cookie Jar Reserve}

This technique of earnings management results from the flexibility of the accounting framework. The essence of this technique is the "storage" of various amounts until it is time to increase or decrease the profit by them according to the current situation and need. The use of international standards or national laws as managers results in an estimate and record of the costs incurred from the events of the current year, even if they become due in the future. It is the estimation of costs that brings with it room for earnings management. If the manager chooses the highest possible amount that can be reasonably justified, he will report higher costs than would be the case with a lower estimate. With this decision, the manager created a "cookie jar reserve", which will be used later when it will be necessary to report lower costs and possible higher earnings. The cookie jar reserve is adopted when the firstperiod outcome does not suffice to meet the thresholds in both periods, but missing the first-period threshold enables the firm to meet or beat expectations in the second period. [17]

\subsubsection{Specific example of Cookie Jar Reserve}

\section{Return of goods}

Receivables should be recorded at net realizable value. This is the final value that will be collected. Therefore, the manager must take into account all possible factors that affect the collection of receivables, such as the return of goods. If managers expect a refund or adjustment of the sale price, they are required to record these facts. Assuming that the goods sold this year will be returned in the concrete amount of thousand euro this fact will be recorded this year, by reporting the cost and the corresponding allowance. The estimated value of returned goods causes earnings management. 


\section{Amortization of inventories}

The historical value of inventories must be reduced to net realizable value, in the event of a significant decrease in their value due to obsolescence, destruction, and changes in prices. One of the two options is the direct write-off of inventories to costs. However, managers of the company can also use a provision that shows inventory allowance. Earnings management is made possible by the process of determining the value of inventories, which cannot be done without a complex estimation process.

\section{Warranty expense}

Complaint costs are included in sales prices, but they also reduce the company's profit in the year of sale of the goods to which they relate, although complaints cannot be made until the beginning of the following year. Determining the value of complaint costs cannot be carried out without an estimation process, which results in profit manipulation.

\subsubsection{Big Bath}

The big bath technique is based on the principle of influencing the accrual of costs. In the current year, they report all possible costs related to revenues, and a profitable future is prepared. This is a technique often used in a management change, where new managers can transfer responsibility for huge losses to their predecessors. The practical significance of this technique lies in the fact that if we expect weak earnings, the company will report an additional loss to make an even worse financial result, which in turn avoids a later loss. This technique appears concerning operational restructuring, impairment of assets, and discontinued operations. Overconfident managers overestimate their abilities and consequently have upwardly biased expectations concerning future firm performance. [18]

\subsubsection{Accounting change}

Earnings management simply arises as a result of possible accounting changes. Companies seeking to change the accounting principle must take the stock market into account because lower earnings quality results in a distortion of the share price. Accounting principles can be changed by company managers without a negative impact on the share price:

- Volunteering for a new accounting standard - voluntary early adoption can provide an opportunity to manage earnings.

- Expense recognition rule - for companies recording certain expenses in cash, a timely change to an accrual-based rule can cause managing earnings. This change is consistent with a change in corporate policies concerning the item. For example, if a company primarily compensated its executives with cash, recording these expenses when paid, a change to a deferred compensation plan could provide an opportunity to record the expense on an accrual basis and lower earnings in the year of adoption. [14]

\subsubsection{Operating and non-operating earnings}

Operating earnings are characterized by regularity and its generation in the future is expected. While non-operating earnings are volatile, it is one-off earnings. Since operating earnings is the analysts' starting point for determining the value of a corporation's shares and is an important accounting item for users of financial statements in general, it is necessary to properly identify its components and consciously try to prevent the effective 
diversion of individual types of profit to create a misleadingly positive or negative image of the financial situation and prosperity of the company. The choice between posting a transaction in operating or non-operating profit is an earnings management technique that is again available due to some accounting flexibility.

\subsubsection{Other accrual-based earnings management techniques}

- recording sales before they are realizable,

- recording fictitious sales,

- overstating inventory by recording fictitious inventory,

- early retirement of debt,

- amortization, depreciation, and depletion,

- change in accounting methods,

- backdating sales invoices,

- overly aggressive recognition of provisions or reserves,

- overvaluation of acquired in-process R\&D in purchase acquisitions,

- overstatement of restructuring charges and assets write-offs,

- understatement of provisions for bad debts,

- drawing down provisions or reserves in an overly aggressive manner. [15]

\section{Conclusion}

In a global environment, there are strong motives for managers to practice earnings management. These motives include better pricing of securities, beating analysts' expectations, avoid negative earnings, show better performance than past, better compensation of managers, tax evasion, external finance attraction, concealment of poor performance, favorite contracts from suppliers, customers, lenders, and employees and avoiding technical default on debts covenants. Another dimension of earnings management is the stress level of managers builds up due to expectations of better performance by stakeholders. In a global environment, there are several techniques used to practice motives leading to earnings management which are divided into two groups according to the type of earnings management. Within real earnings management, the most frequently used techniques for earnings management are big bet on the future, flushing investment portfolio, throw out and shrink the ship. In addition to these techniques, delaying sales, accelerating $\mathrm{R} \& \mathrm{D}$ or advertising expenditures, postponing $\mathrm{R} \& \mathrm{D}$ or advertising expenditures, sale/leaseback, and asset exchange techniques are also used for earnings management. Accrual-based earnings management uses techniques such as cookie jar reserve, with specific examples being the return of goods, amortization of inventories, and warranty expense. Other techniques are a big bath, accounting change, and operating and non-operating earnings. Accrual-based earnings management also uses other earnings management techniques such as recording sales before they are realizable, recording fictitious sales, overstating inventory by recording fictitious inventory, early retirement of debt, amortization, depreciation, and depletion, change in accounting methods, backdating sales invoices, overly aggressive recognition of provisions or reserves, overvaluation of acquired in-process R\&D in purchase acquisitions, overstatement of restructuring charges and assets write-offs, understatement of provisions for bad debts, drawing down provisions or reserves in an overly aggressive manner. 
This paper was prepared with the support of APVV-17-0546 Variant Comprehensive Model of Earnings Management in Conditions of The Slovak Republic as an Essential Instrument of Market Uncertainty Reduction which author gratefully acknowledges.

\section{References}

1. Khanh, M. T. H, Thu, P. A. (2019). The effect of financial leverage on real and accrual-based earnings management in Vietnamese firms. Economics and Sociology, 12(4), 299-312.

2. Durana, P., Valaskova, K., Chlebikova, D., Krastev, V., Atanasova, I. (2020). Heads and Tails of Earnings Management: Quantitative Analysis in Emerging Countries. Risks, 8(2), 57.

3. Onuferova, E., Cabinova, V., Dzurov Vargova, T. (2020). Analysis of modern methods for increasing and managing the financial prosperity of businesses in the context of performance: a case study of the tourism sector in Slovakia. Oeconomia Copernicana, 11(1), 95-116.

4. Siekelova, A., Podhorska, I. (2020). Earnings Indicators under the Condition of Globalization. SHS Web of Conferences, 74, 01031.

5. Khuong, N. V., Liem, N. T., Minh, M. T. H. (2020). Earnings management and cash holdings: Evidence from energy firms in Vietnam. Journal of International Studies, 13(1), 247-261.

6. Svabova, L., Kramarova, K., Chutka, J., Strakova, L. (2020). Detecting earnings manipulation and fraudulent financial reporting in Slovakia. Oeconomia Copernicana, 11(3), 485-508.

7. Kramarova, K., Valaskova, K. (2020). Application of Chosen Fraudulent Detection Technique in the Slovak Business Environment. In SHS Web of Conferences, 74, 01019.

8. Chen, M. CH., Sheng, CH. W. (2013). Workplace Spirituality and Earnings Management Motivations. International Journal of Business and Information, 8(2), 267-298.

9. Healy, P. (1985). The impact of bonus Schemes on the selection of accounting principles. Journal of Accounting and Economics, 7(1-3), 85-107.

10. Rahman, M., Moniruzzaman, M., Sharif, J. (2013, September 9). Techniques, Motives and Controls of Earnings Management. http://www.significance.co.uk/index.php/JASR/article/view/198/200

11. Kovacova, M., Kliestik, T., Valaskova, K., Durana, P., Juhaszova, Z. (2019). Systematic review of variables applied in bankruptcy prediction models of Visegrad group countries. Oeconomia Copernicana, 10(4), 743-772.

12. Sweeney, A. P. (1994). Debt-covenant violations and managers' accounting responses. Journal of Accounting and Economics, 17(3), 281-308.

13. Watts, R., Zimmerman, J. (1986). Positive accounting theory. Englewood Cliffs, New Jersey: Prentice Hall.

14. Ayu, M., Gamayuni, R. R., Urbanski, M. (2020). The impact of environmental and social costs disclosure on financial performance mediating by earning management. Polish Journal of Management Studies, 21(1), 74-86.

15. Fogel-Yaari, H. Ronen, J. (2020). Earnings management strategies for meeting or beating expectations. Journal of Accounting and Public Policy, 39(1), 1-20. 
16. Ozili, P. K. (2017). Earnings management in interconnected networks: a perspective. Journal of Economic and Administrative Science, 33(2), 150-163.

17. Wroblewski, D. R. (2016). The complex vision on the earnings management: the evidence from Eastern European countries. Zaragoza: Universidad de Zaragoza.

18. Rahman, M., Moniruzzaman, M., Sharif, J. (2012, September 9). Techniques, Motives and Controls of Earnings Management.

https://www.jitbm.com/11th\%20Volume/rehman.pdf 